\title{
Immunosuppressant FK506 Induces Interleukin-6 Production through the Activation of Transcription Factor Nuclear Factor (NF)-кB Implications for FK506 Nephropathy
}

\author{
Kei-ichi Muraoka, ${ }^{\star \ddagger}$ Koutaro Fujimoto, ${ }^{\star}$ Xiangao Sun, ${ }^{\star}$ Katsuji Yoshioka, ${ }^{\star}$ Kou-ichi Shimizu, ${ }^{\ddagger}$ Masao Yagi, ${ }^{\ddagger}$ Henry Bose, Jr., ${ }^{\S}$ \\ Itsuo Miyazaki, ${ }^{\ddagger}$ and Ken-ichi Yamamoto* \\ *Department of Molecular Pathology, Cancer Research Institute; ${ }^{\ddagger}$ Department of Surgery (II), School of Medicine, Kanazawa University, \\ 13-1 Takaramachi, Kanazawa, Ishikawa 920, Japan; ${ }^{\S}$ Institute for Cellular and Molecular Biology, The University of Texas at Austin, \\ Austin, Texas 78712-1095
}

\begin{abstract}
FK506 is a powerful immunosuppressive drug currently in use that inhibits the activation of several transcription factors (nuclear factor (NF)-AT and NF- $\kappa \mathrm{B}$ ) critical for T cell activation. We show here that, contrary to the situation in $\mathrm{T}$ cells, FK506 activates transcription factor NF- $\mathrm{B}$ in nonlymphoid cells such as fibroblasts and renal mesangial cells. We further show that FK506 induces NF-кB-regulated IL-6 production in vitro and in vivo, in particular in kidney. IL-6 has been shown previously to produce renal abnormalities in vivo, such as mesangioproliferative glomerulonephritis. Similar renal abnormalities were also observed in FK506treated animals. These results thus suggest a causal relationship between FK506-induced NF- $\mathrm{B}$ activation/IL-6 production and some of FK506-induced renal abnormalities. (J. Clin. Invest. 1996. 97:2433-2439.) Key words: immunosuppressant • FK506 • NF-KB • IL-6 • nephrotoxicity
\end{abstract}

\section{Introduction}

FK506 is a recently introduced powerful immunosuppressive drug that exerts its major immunosuppressive effect by inhibiting events including transcriptional activation of several cytokine genes, particularly of the IL-2 gene, which leads to T cell activation (1). By complexing with an FK506 binding protein (FKBP12), a member of the immunophilin protein family, FK506 inhibits the activity of calcineurin, $\mathrm{Ca}^{2+} /$ calmoduli-activated phosphatase (2). This calcineurin inhibition in turn blocks the phosphatase-controlled translocation of transcription factor nuclear factor $(\mathrm{NF})^{1}$-AT to the nucleus; NF-AT is one of most important transcription factors involved in the activation of the IL-2 gene $(3,4)$. Cyclosporin A (CsA) is another immunosuppressive drug inhibiting this calcineurin/NF-

Address correspondence to Ken-ichi Yamamoto, Department of Molecular Pathology, Cancer Research Institute, Kanazawa University, 13-1 Takaramachi, Kanazawa, Ishikawa 920, Japan; Phone: 762-344516; FAX: 762-34-4517.

Received for publication 24 October 1995 and accepted in revised form 14 March 1996.

1. Abbreviations used in this paper: CsA, cyclosporin A; EMSA, electrophoretic mobility shift assay; NF, nuclear factor.

J. Clin. Invest.

(C) The American Society for Clinical Investigation, Inc.

0021-9738/96/06/2433/07 \$2.00

Volume 97, Number 11, June 1996, 2433-2439
AT/IL-2 pathway, through complex formation with other members of the immunophilin family, cyclophilin (2-4).

7FK506 and CsA also inhibit the activation of other transcription factors involved in IL-2 gene expression in $\mathrm{T}$ cells

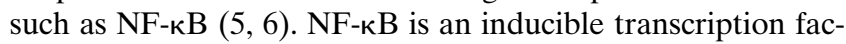
tor essential for the activation of various cytokines genes, not only of the IL-2 gene but also of several important inflammatory cytokine genes such as the IL- 6 and IL- 8 genes. NF- $\mathrm{B}$ is a heterodimer containing two subunits of 50 and $65 \mathrm{kD}$ termed p50 and p65 and preexists in the cytoplasm in an inactive form complexed with inhibitory proteins termed I $\mathrm{B} \alpha$. Various stimuli activate NF-кB through the proteolytic degradation of IкB $\alpha$ (7-9). In T cells, extracellular stimuli and intracellular signal transduction pathways similar to those involving calcineurin and leading to NF-AT activation are also involved in $\mathrm{I} \kappa \mathrm{B} \alpha$ degradation and NF- $\mathrm{B}$ activation. Calcineurin thus appears to be also a major target for FK506-FKBP12 and CsA-cyclo-

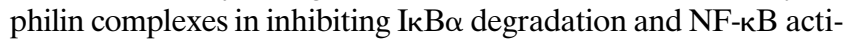
vation (5). By contrast, the results of recent studies indicated that another immunosuppressive drug, glucocorticoid, inhibits $\mathrm{NF}-\kappa \mathrm{B}$ activation through induction of $\mathrm{I} \kappa \mathrm{B} \alpha$ synthesis $(10,11)$.

Although the immunosuppressive drug FK506 and CsA are widely used in clinical transplantation, various side effects of these drugs, particularly nephrotoxity, limit their usefulness in widespread applications such as the possible treatment of autoimmune diseases (12-14). However, it is not clearly established yet how these drugs cause renal abnormalities in vivo. We show here that, contrary to the situation in T cells, FK506 induces NF- $\mathrm{B}$ activation in nonlymphoid cells such as renal mesangial cells and fibroblasts. We further show that, as a result of NF-кB activation by FK506, FK506 induces the production of a pleiotropic inflammatory cytokine, IL-6 (15), in kidney. IL-6 has been shown previously to produce renal abnormalities in vivo, such as mesangioproliferative glomerulonephritis (16-19). Similar renal abnormalities were also reported in FK506-treated animals (20) and are shown in the present study. The results of the present study therefore raise the possibility of a causal relationship between FK506-induced NF- $\kappa \mathrm{B}$ activation/IL-6 production and some FK506-induced renal abnormalities.

\section{Methods}

Cell culture and analysis of $I_{\kappa} B \alpha$ degradation. Mouse L-TK cells were grown in DME supplemented with $10 \%$ FCS. Mouse mesangial cells (SV40 MES 13, CRL 1927; American Type Culture Collection, Rockville, MD) were grown in a 3:1 mixture of DME and Ham's F12 medium, supplemented with FCS (5\%) and 14 mM Hepes. The IкB $\alpha$ expression vector was constructed by cloning an entire avian IкB $\alpha$ (pp40) coding sequence (21) in a correct orientation into an eukary- 
otic expression vector driven by a human elongation factor-1 promoter (22). L-TK cells were transfected with $10 \mu \mathrm{g}$ of ІкB $\alpha$ expression plasmids by the DEAE-dextran method as described previously (23). $48 \mathrm{~h}$ after transfection, cells were treated with FK506 for the times indicated, and cell extracts were prepared for Western blot analysis with anti-pp40 antibodies (21). Western blot analysis was carried out by ECL Western blotting (Amersham Corp., Arlington Heights, IL) according to the manufacturer's recommendation.

Electrophoretic mobility shift assay (EMSA), Northern blot analysis and ELISA. Nuclear extracts were prepared by the method of Dignam et al. (24). EMSA, preparation, and labeling of the IL-6кB probe (GGGATTTTCCC) used in EMSA, and antibody supershift EMSA were performed as described previously $(23,25)$. Antibodies reactive for mouse NF-кB-p50 and -p65 were obtained from Santa Cruz Biotechnology, Inc. (Santa Cruz, CA). Total RNA was prepared as described previously (26). An entire mouse IL-6 cDNA coding region (PCR amplified, cloned, and provided by Yoshida and Taga, Osaka University, Osaka, Japan) was hybridized against $20 \mu \mathrm{g}$ of RNA. A $\beta$-actin probe containing a part of the human $\beta$-actin exon 3 (27) was later used to reprobe the same blot. Levels of IL-6 mRNA were quantitated by Fujix Bio-image-analyzer (Fuji Film Co., Tokyo, Japan) and normalized to $\beta$-actin. IL- 6 concentrations in culture supernatants of SV40 MES13 cells were determined with an ELISA kit (Endogen Inc., Boston, MA) according to the manufacturer's recommendation. The 24-h trough levels in the whole blood and kidney tissue levels of FK506 were measured by ELISA with an mAb directed against FK506 (Fujisawa Pharmaceutical Co., Ltd, Osaka, Japan); extraction of FK506 was performed by an organic solvent method using dichloromethane (28).

Animals studies. Male DDY mice weighing $30 \mathrm{~g}$ were divided into two groups. One group of mice were intramuscularly injected with $5 \mathrm{mg} / \mathrm{kg}$ per d of FK506 (Fujisawa Pharmaceutical Co., for 2, 4, 6, or $8 \mathrm{wk}$, and the other group of mice (control group) were injected with a FK506 vehicle alone. Mice were killed and kidneys were obtained for histological and immunohistochemical studies. FK506 level monitoring in these mice were performed as described above. IL- 6 levels of urine samples from these mice were determined with the ELISA kit as described above. For light microscopy study, kidney tissues were fixed with $10 \%$ formarin and embedded in paraffin. Sections (4 $\mu \mathrm{m})$ were stained with hematoxylin/eosin or periodic acid-Schiff reagents. Immunohistochemical staining of IL-6 was performed as follows: Kidney tissues were fixed in cold acetone (100\%) for $10 \mathrm{~min}$ before staining. Tissue sections were air dried and were incubated with $0.1 \%$ BSA for $30 \mathrm{~min}$ at $4^{\circ} \mathrm{C}$ and then with rabbit serum (Vector Laboratories Inc., Burlingame, CA) for an additional 30 min to block nonspecific binding. Sections were subsequently incubated with anti-mouse IL-6 antibody (R\&D Systems, Minneapolis, MN) at $4^{\circ} \mathrm{C}$ overnight, and, after washing with PBS, were incubated further with biotinated rabbit anti-goat Ig (Vectastain ABC kit; Vector Laboratories Inc.) for $30 \mathrm{~min}$. Sections were rinsed again with PBS and were reacted with avidine peroxidase for $30 \mathrm{~min}$ and with diaminobenzidine for 3 min. Finally, sections were rinsed and counterstained with methylgreen.

\section{Results}

The results of several previous studies showed that both CsA and FK506 inhibit NF-кB activation in T cells, presumably through their actions on calcineurin $(5,6)$. However, the effects of these immunosuppressive drugs on NF-кB activation in nonlymphoid cells have not been tested previously, and FK506 and related rapamycin exert various activities in intracellular signal transduction in nonlymphoid cells (29). For these reasons, we were interested whether these immunosuppressive drugs show any effects on NF-кB activation in nonlymphoid cells. We first tested the effects of these drugs on $\kappa \mathrm{B}$-dependent transcriptional activation in fibroblast L-TK cells. The IL-6 promoter-CAT fusion gene containing the 225-bp human IL-6 promoter region was used as a reporter for $\kappa \mathrm{B}$-dependent transcriptional activation, as it has been well established that the activation of the IL- 6 promoter by various activators, including IL-1, is primarily regulated by NF-кB (23). The results showed that, while CsA inhibited IL-6 promoter activation induced by IL-1 in a dose-dependent manner as in T cells, FK506 did not inhibit but rather enhanced slightly IL-1-induced IL-6 promoter activation (data not shown). Furthermore, FK506 itself and the structually related rapamycin, but not CsA, induced IL-6 promoter activation at a higher dose $(10 \mu \mathrm{M})$; this FK506/rapamycin-induced
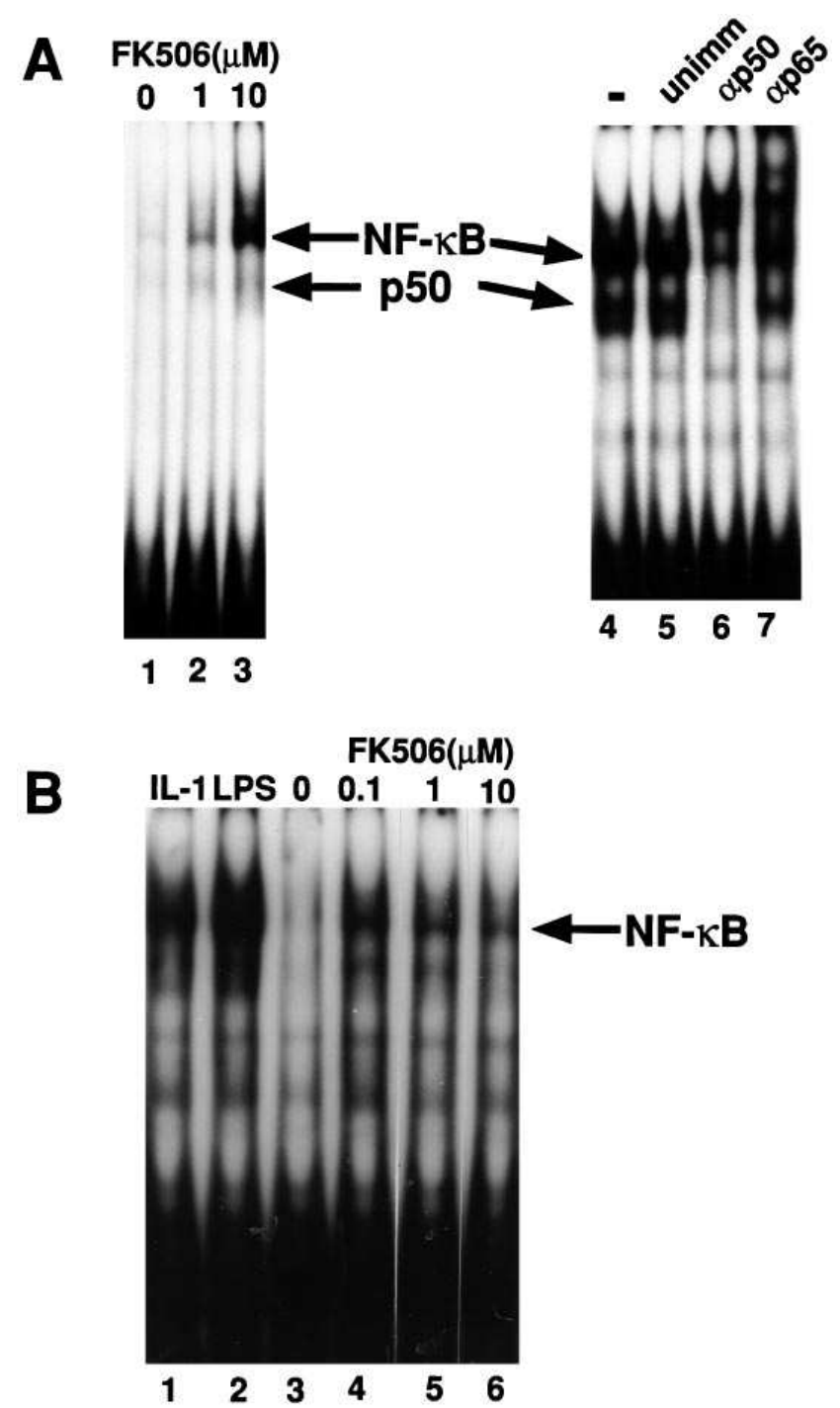

Figure 1. FK506 activates NF-кB in nonlymphoid cells. L-TK $(A)$ or mouse mesangial cells $(B)$ were treated for 30 min with IL-1 $(21 \mathrm{ng} /$ $\mathrm{ml})$, LPS $(10 \mu \mathrm{g} / \mathrm{ml})$ or various concentrations of FK506 as indicated, and nuclear extracts were prepared and analyzed on EMSA with the IL-6 кB motif as a probe. In antibody super-shift EMSA ( $A$, lanes 4-7), before to assay, $1 \mu \mathrm{l}$ of unimmunized sera (lane 5) or anti $(\alpha)$-NFкBp50 (lane 6) or -NF-кBp65 (lane 7) antisera were added to nuclear extracts prepared from L-TK cells which were treated for $30 \mathrm{~min}$ with FK506 $(10 \mu \mathrm{M})$. NF-кB (p50-p65 heterodimer) and p50 homodimers are indicated by arrows. 
FK506
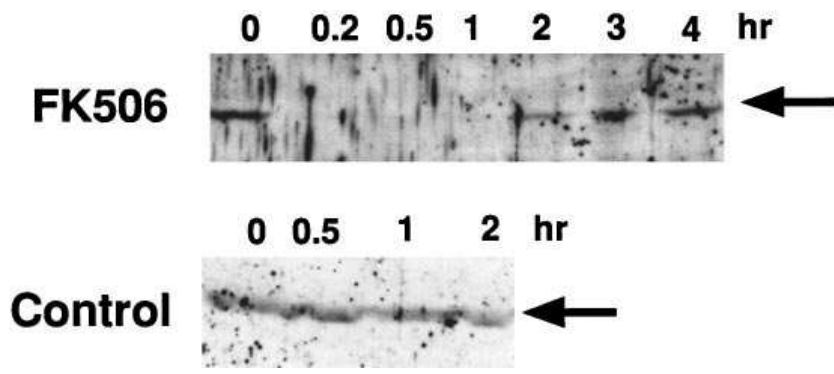

Figure 2. FK506 induces IкB $\alpha$ degradation. L-TK cells were transfected with an avian IкB $\alpha$ expression vector $(10 \mu \mathrm{g})$ and were then untreated (Control) or treated with FK506 $(10 \mu \mathrm{M})$ for various times as indicated. Cell extracts were subjected to Western blot analysis with anti-avian $\mathrm{I} \kappa \mathrm{B} \alpha$ sera. The arrow indicates $\mathrm{I} \kappa \mathrm{B} \alpha$.

IL-6 promoter activation was completely dependent on the IL-6 $\mathrm{\kappa B}$ motif (data not shown).

Since FK506 most strongly activated $\kappa \mathrm{B}$-dependent transcription, we next studied whether FK506 induces NF-кB activation. Nuclear extracts were prepared from L-TK cells treated for 30 min with 1 or $10 \mu \mathrm{M}$ FK506 and were analyzed on EMSA with the IL- 6 кB motif as a probe. As shown in Fig. $1 A$, treatment with 1 and $10 \mu \mathrm{M}$ FK506 resulted in the appearance of two $\mathrm{\kappa B}$-binding activities (lanes 2 and 3); the slow- and fast-migrating $\kappa \mathrm{B}$-binding activities had mobilities comparable to those of NF-kB (a p65/p50 heterodimer) and p50 homodimers and were identified as NF- $\mathrm{B}$ and p50 homodimers, respectively, based on their reactivities for anti-p65 or -p50 antibodies (lanes 6 and 7). We were also interested to see whether FK506 activates NF-кB in other types of nonlymphoid cells. For this experiment, we selected a mouse renal mesangial cell line, since this cell line produces IL-6, the gene that is an important target for NF-кB (23). As shown in Fig. 1 $B$, FK506 activated NF-кB in mesangial cells at much lower concentrations $(0.1 \mu \mathrm{M})$. In additional experiments, we analyzed the same cell extracts on EMSA with a probe specific for the AP-1 transcription factor to test whether FK506 specifically activates the NF-кB transcription factor. The results show that AP-1 is not significantly activated by $10 \mu \mathrm{M}$ FK506 (data not shown). We then examined whether FK506 induces I $\mathrm{B} \alpha$ degradation, since $\mathrm{I} \kappa \mathrm{B} \alpha$ is a major inhibitor of NF-кB and its degradation in response to various activators is an essential step leading to NF-кB activation (8). An expression vector encoding avian $\mathrm{I} \kappa \mathrm{B} \alpha$ (pp40) was transfected into L-TK cells, and cells were treated with $10 \mu \mathrm{M}$ FK506 for various times; cell extracts were subjected to Western blot analysis with anti-pp40 antibodies. Fig. 2 shows that FK506 induced a transient $\mathrm{I} \kappa \mathrm{B} \alpha$ degradation as seen with other typical NF- $\mathrm{NB}$ activators such as IL-1.

The above results clearly showed that FK506 activates NF $\kappa \mathrm{B}$ in nonlymphoid fibroblastic and mesangial cell lines. Since renal mesangial cells have been shown previously to produce IL-6 (16), we examined whether this FK506-induced NF-кB activation leads to the induction of endogeneous IL-6 gene expression and to IL-6 production. After exposure of mesangial cells with 0.5 or $10 \mu \mathrm{M}$ FK506 for various times, levels of IL-6 mRNA and IL-6 proteins secreted in culture supernatants were analyzed with Northern blot analysis and ELISA, respectively. As shown in Fig. 3, the exposure of mesangial cells to
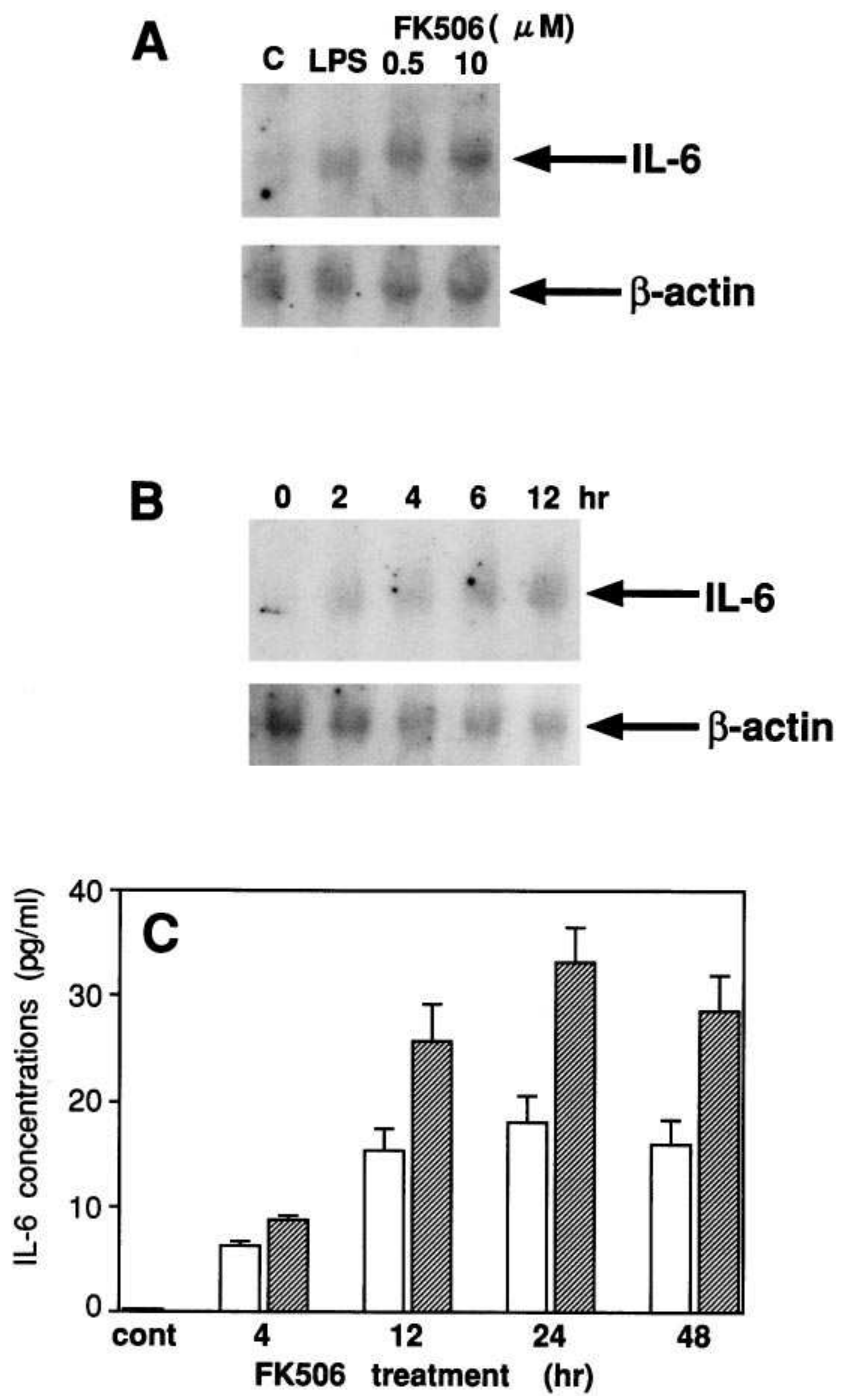

Figure 3. FK506 induces IL-6 gene expression and IL-6 production in mesangial cells in vitro. $(A$ and $B$ ) The induction of endogeneous IL-6 gene expression. Mouse mesangial cells were untreated $(C)$, or treated with either LPS $(10 \mu \mathrm{g} / \mathrm{ml})$ or FK506 $(0.5$ and $10 \mu \mathrm{M})$ for $12 \mathrm{~h}$ $(A)$, or were treated with $10 \mu \mathrm{M}$ FK506 for various times $(B)$, as indicated. Total cellular RNA $(20 \mu \mathrm{g})$ was prepared and hybridized with mouse IL- 6 cDNA and human $\beta$-actin probes. $(C)$ The induction of IL-6 production. Mesangial cells were untreated (cont) or treated with FK506 $(0.5 \mu \mathrm{M}$, open bar; $10 \mu \mathrm{M}$, hatched bar $)$ for various times as indicated, and concentrations of IL- 6 proteins secreted into culture supernatants were quantitated with ELISA.

$0.5 \mu \mathrm{M}$ FK506 resulted in the induction of endogeneous IL-6 gene expression as well as IL-6 production.

The results that FK506 induces IL-6 gene expression and IL-6 production through NF- $\mathrm{B}$ activation in vitro prompted us to examine whether FK506 also induces IL-6 production in vivo. Furthermore, since abnormal IL-6 production in vivo has been shown previously to produce renal abnormalities such as mesangioproliferative glomerulonephritis (16-19) and since similar renal abnormalities have also been reported in FK506 treated animals (20), it is of interest to investigate a possible causal relationship between FK506-induced NF-кB activation and FK506-induced renal abnormalities. We first quantitated 
FK506 levels in whole blood (trough) and tissues, particularly in kidneys, after FK506 administration in mice to see what trough FK506 levels are observed, or whether tissue FK506 levels observed are comparable to FK506 concentrations effective for NF- $\mathrm{kB}$ activation in vitro $(>0.1 \mu \mathrm{M}$ or $82 \mathrm{ng} / \mathrm{ml}$, see Figs. 1 and 3). With the FK506 dose of $0.5 \mathrm{mg} / \mathrm{kg}$ per d, which is close to the clinical dose of $0.1-0.2 \mathrm{mg} / \mathrm{kg}$ per $\mathrm{d}$ in humans, we observed the mean trough level of $4.8 \mathrm{ng} / \mathrm{ml}$ and the kidney tissue level of $>150 \mathrm{ng} / \mathrm{g}$ of tissue after 8 wk of FK506 administration (data not shown). This tissue FK506 level in kidney might be sufficient for NF-kB activation in vivo. However, the results of previous clinical studies indicated that renal toxicity is more frequent in patients with FK506 trough levels higher than $20 \mathrm{ng} / \mathrm{ml}$ (12). We therefore tested a higher FK506 administration dose ( $5 \mathrm{mg} / \mathrm{kg}$ per d). As shown in Fig. 4, the trough and kidney tissue FK506 levels were 20-60 ng/ml and 250-600 $\mathrm{ng} / \mathrm{g}$ of tissue, respectively, after 8 wk of this high FK506 dose. We therefore adopted this FK506 dose in the subsequent in vivo study to study FK506-mediated IL-6 production in vivo and FK506-induced renal abnormalities or toxicity. The results shown in Fig. 4, in addition, indicate that tissue FK506 levels are much higher than trough FK506 levels. These results are in good agreement with those of the previous preclinical and clinical studies (30) and suggest that FK506 tends to accumulate in tissues, presumably due to its lipophilic nature.

Since IL-6 production in vivo, in particular in kidney, is expected to increase urinary IL-6 levels, we quantitated urinary IL-6 levels of mice treated with FK $506(5 \mathrm{mg} / \mathrm{kg}$ per d) for various periodes. As shown in Fig. 5, FK506 treatment resulted in a significant increase in urinary IL-6 levels. To further verify that FK506 induces IL-6 production in vivo, we performed immunohistochemical analysis of kidney tissue sections from mice treated with FK506 for 8 wk. The results are shown in Fig. 6. While we could not detect significant IL-6 staining in kidney tissues from control mice (Fig. $6 \mathrm{~A}$ ), in agreement with the lack of detectable IL-6 in urine samples from these mice (Fig. 5), significant staining of IL-6 in kidney tissues from mice treated with FK506 was observed: in particular, mesangial cells

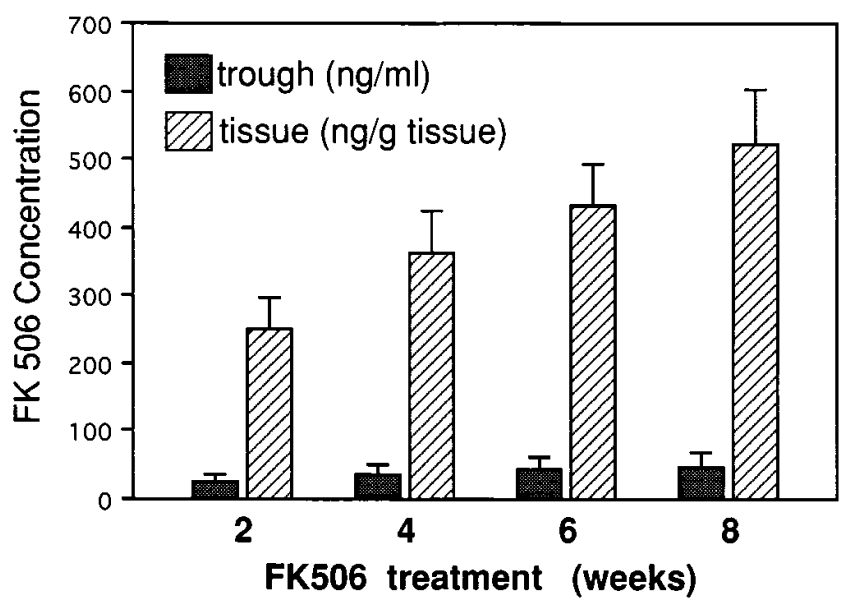

Figure 4. Whole blood and tissue FK506 concentrations after FK506 administration. Mice were intramuscularly injected with $5 \mathrm{mg} / \mathrm{kg}$ per $\mathrm{d}$ of FK506 for 2, 4, 6, or $8 \mathrm{wk}$, and whole blood (trough, ng/ml; shaded bar) and tissue (ng/g of tissue; hatched bar) FK506 levels were determined with ELISA.

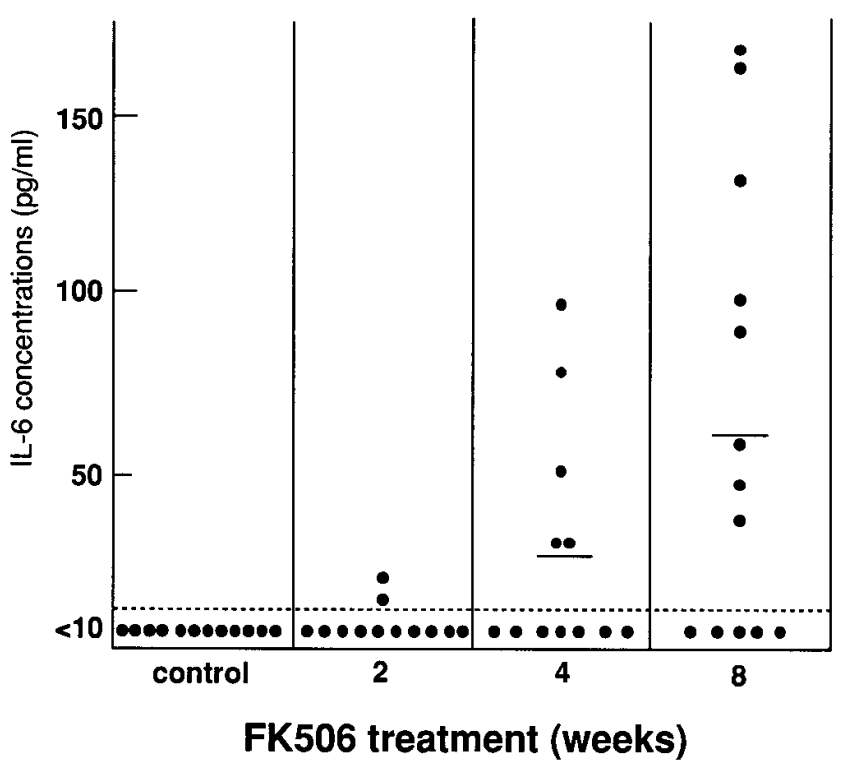

Figure 5. Enhanced urinary IL-6 excretion after FK506 treatment. Mice were intramuscularly injected with $5 \mathrm{mg} / \mathrm{kg}$ per d of FK506 for $2,4,6$, or $8 \mathrm{wk}$ or with a FK506 vehicle alone (control) as described in Methods. Urine samples were collected from these mice, and IL-6 concentrations were determined with ELISA.

(Fig. $6 \mathrm{C}$ ) and, to a lesser extent, tubular cells (Fig. $6 \mathrm{~B}$ ) showed a strong IL-6 staining.

The major histological abnormalities observed in the kidneys of FK506-treated mice were mesangial cell proliferation and an increase in mesangial matrix (Fig. $7 \mathrm{~B}$ ), which are suggestive of mesangioproliferative glomerulonephritis, and foamy vacuolization of proximal tubular cells (tubular vacuolization) (Fig. $7 \mathrm{C}$ ). These histological abnormalities were also noted in previous studies $(20,31,32)$.

\section{Discussion}

FK506, a most powerful immunosuppressant currently used, inhibits the activation of several transcription factors involved in cytokine gene expression in T cells, including NF-kB. The results presented in this paper, on the contrary, show that FK506 activates NF-кB through ІкB $\alpha$ degradation in nonlymphoid cells (Figs. 1 and 2) and that this FK506-induced NF-KB activation results in efficient induction of IL-6 production in vitro and in vivo (Figs. 3, 5, and 6). Although these results indicate that signal transduction pathways leading to NF- $\mathrm{BB}$ activation in lymphoid cells and nonlymphoid cells are different, they, more importantly, raise two critical questions. One is how FK506 activates NF-кB. The other is what are the clinical implications of in vivo FK506-mediated IL-6 production, particularly in kidney.

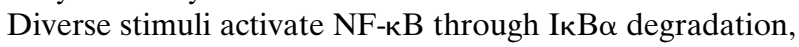
and reactive oxygene intermediates have been implicated as a common intracellular messenger in signal transduction leading

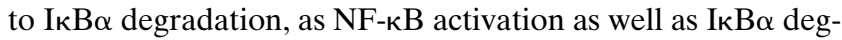
radation is blocked by antioxidants such as $N$-acetylcycteine (33). The results that FK506 activates NF-кB through IкB $\alpha$ degradation (Figs. 1 and 2) and that this FK506-induced IкB $\alpha$ degradation and NF- $\mathrm{kB}$ activation is blocked in the presence 

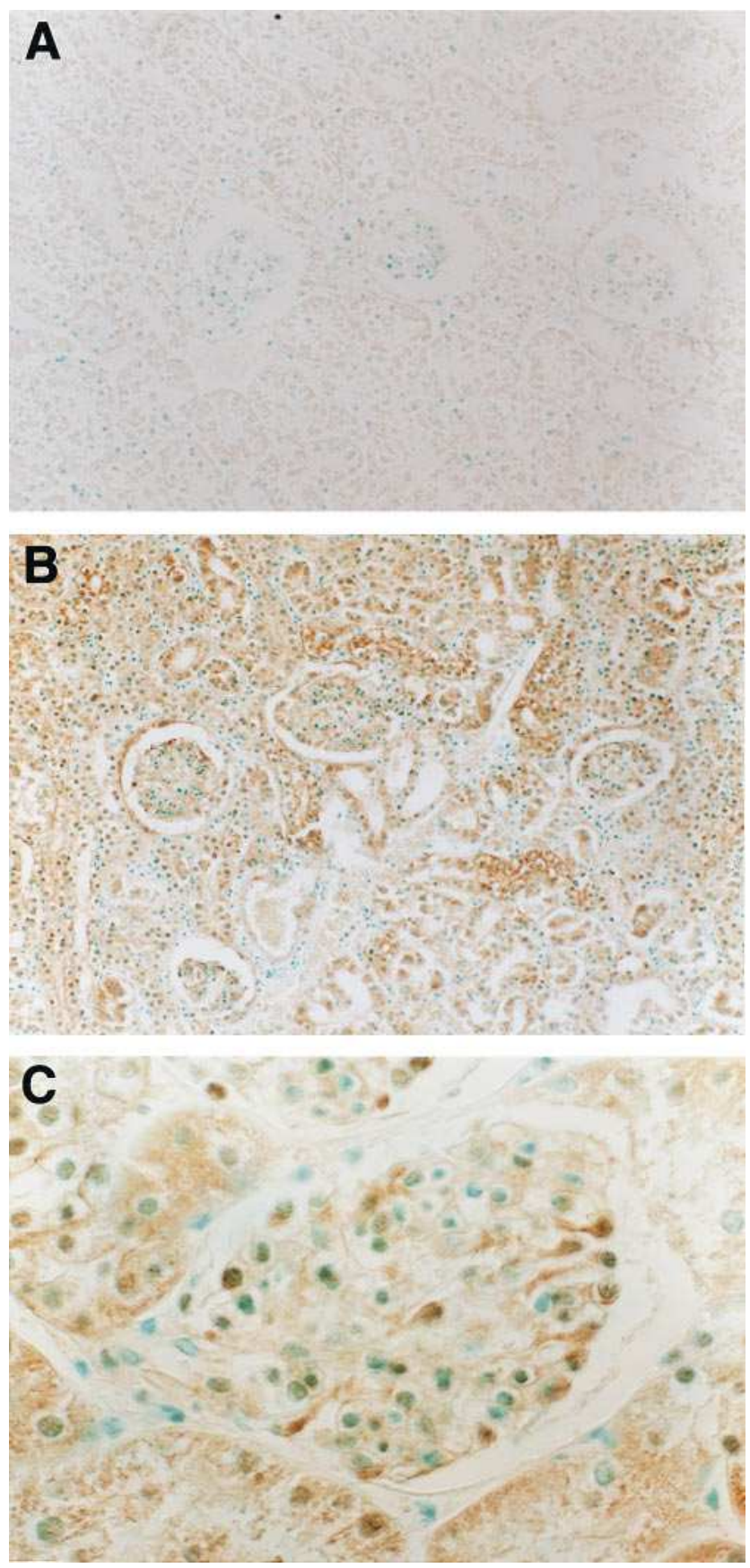

Figure 6. Immunohistochemical detection of IL-6 proteins in kidney of FK506-treated mice. Kidney tissue sections were prepared from control mice $(A)$ or from mice treated with FK506 (5 mg/kg per d) for 8 wk $(B$ and $C)$ as described in Methods. Sections were then processed for immunohistochemistry. Original magnification: $A$ and $B$, $\times 100 ; C, \times 400$.

of $\mathrm{N}$-acetylcycteine (unpublished data), therefore, indicate that FK506 uses a similar physiological signal transduction pathway involving reactive oxygene intermediates and leading to $\mathrm{I} \kappa \mathrm{B} \alpha$ degradation. We also observed that FK506 activates MAP kinase (unpublished data), which is also activated by various NF- $\mathrm{KB}$ activating agents including IL-1 and LPS (34). This again indicates that FK506 can use physiological cellular
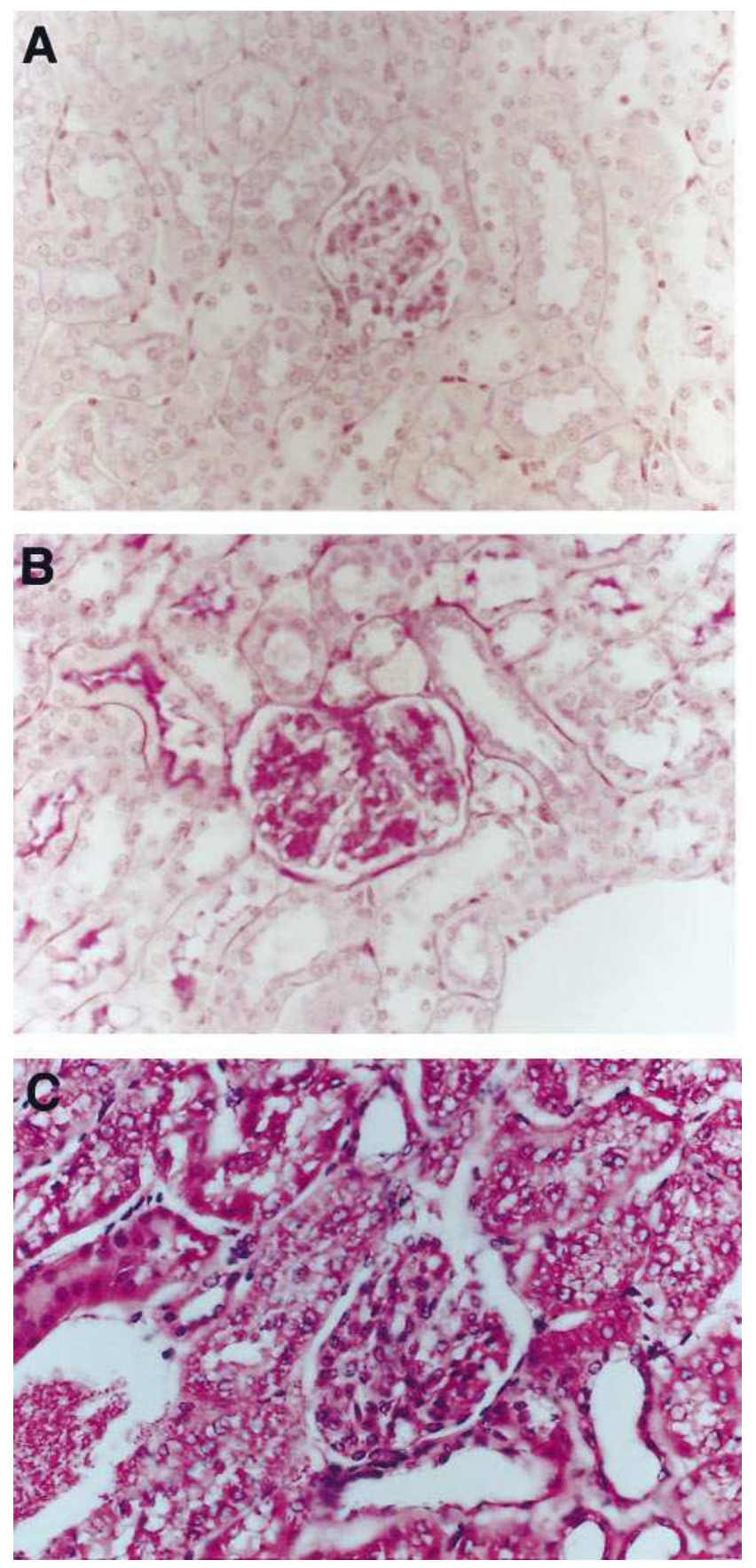

Figure 7. Histopathological abnormalities in kidney of FK506treated mice. Kidney tissue sections from control mice $(A)$ or from mice treated with FK506 (5 mg/kg per d) for 8 wk ( $B$ and $C)$ were stained with periodic acid-Schiff reagents ( $A$ and $B$ ) or hematoxylin/ eosin $(C)$. Original magnification, $\times 200$.

signal transduction pathways. However, we do not know at present what cellular signal transduction pathways are used by FK506 for NF- $\mathrm{B}$ activation in nonlymphoid cells. Calcineurin is apparently not involved in this FK506-induced NF- $\mathrm{B}$ activation in nonlymphoid cells, since both of CsA and FK506, but not rapamycin, inhibit calcineurin activity (2). Another possible candidate is c-Raf which has been recently shown to inter- 
act with FK506 through an unidentified FK506 binding protein (35) and has been implicated in NF- $\mathrm{BB}$ activation (36). It is also possible that FK506 activates NF- $\mathrm{KB}$ through its actions on a calcium release channel (37). Further work is clearly required to identify FK506 binding proteins and cellullar factors involved in FK506-induced NF- $\mathrm{B}$ activation.

Although FK506 is a powerful immunosuppressant, its usefulness as an immunosuppressant and its potential clinical applications to other diseases such as rheumatoid arthritis is hampered by its side effects, in particular its nephrotoxity (1214). Major histopathological abnormalities observed in kidney after FK506 treatment are mesangial cell proliferation, mesangial matrix increase, and tubular vacuolization $(20,31,32)$, as also shown in this study (Fig. 7). It is not, however, clear how FK506 produces these renal abnormalities. The present study showed that as little as $0.1 \mu \mathrm{M}$ of FK506 effectively activates $\mathrm{NF}-\kappa \mathrm{B}$ in nonlymphoid cells, such as renal mesangial cells (Fig. 1). NF-кB is an important transcription factor involved in the activation of several inflammatory cytokine genes including the IL-6 gene (9). In particular, NF-кB activation is essential for IL-6 gene expression as shown in in vitro (23) and in vivo knockout mice (38) studies. We indeed showed that FK506 induces IL-6 production in mesangial cells (Fig. 3) and observed IL-6 production in kidney after FK506 treatment of mice (Figs. 5 and 6). IL-6 has been shown previously to induce mesangial cell proliferation and matrix increase in vitro (16) and to produce renal abnormalities such as mesangioproliferative glomerulonephritis in vivo (16-19). Thus, IL-6 production in kidney induced by FK506 through NF-кB activation appears to be responsible for similar renal abnormalities (mesangioproliferative glomerulonephritis) observed in FK506treated animals.

In the present in vivo study, we adopted the high FK506 dose (5 mg/kg per d) to study FK506 renal toxicity (12). While this FK506 dose is much higher than the clinical dose in human (0.1-0.2 $\mathrm{mg} / \mathrm{kg}$ per d), several observations suggest that sufficient FK506 accumulates to activate NF- $\mathrm{BB}$ and to cause renal abnormalities after prolonged FK506 treatment even with low FK506 doses. First, as shown in Fig. 4 as well as reported previously (30), FK506 has a tendency to accumulate in tissues due to its lipophilic nature. We indeed observed FK506 tissue levels of as high as $150 \mathrm{ng} / \mathrm{g}$ tissue after $8 \mathrm{wk}$ of FK506 treatment with the FK506 dose of $0.5 \mathrm{mg} / \mathrm{kg}$ per d (data not shown). Second, different types of cells show different sensitivity to FK506-induced NF-кB activation and as little as $0.1 \mu \mathrm{M}$ (82 $\mathrm{ng} / \mathrm{ml})$ FK506 is sufficient for NF-кB activation in renal mesangial cells (Fig. 1). Third, it has been reported that renal abnormalities are late onset (4-8 wk) in clinical studies in which FK506 doses of $0.15-0.3 \mathrm{mg} / \mathrm{kg}$ per d were used $(12,31)$.

A possible causative relationship of the present finding to other FK506-mediated renal abnormalities, such as tubular vacuolization (Fig. 7), is not clear at present, though we also detected IL-6 in renal tubular cells (Fig. 6). Since CsA, which cannot activate but rather inhibits NF- $\mathrm{B}$, has been also reported to produce similar tubular cell abnormalities but not mesangioproliferative glomerulonephritis $(32,39)$, it is more likely that different mechanisms common to FK506 and CsA are probably involved in this type of renal abnormality (40).

In summary, the present study shows FK506-mediated NF- $\mathrm{B}$ activation and IL-6 production, and further implicates its relationship to some of FK506-induced nephropathy. It is, therefore, possible that in the future the development of effec- tive NF-кB inhibitors will allow more widespread clinical applications of this immunosupressive drug.

\section{Acknowledgments}

We thank T. Taga and K. Yoshida for mouse IL-6 cDNA, and T. Maruyama (Marine Biotechnology Institute, Japan) for rapamycin.

This work was supported in part by Grants-in-Aid from the Ministry of Education, Science and Culture of Japan.

\section{References}

1. Schreiber, S.L., and G.R. Crabtree. 1992. The mechanism of action of cyclosporin A and FK506. Immunol. Today. 13:136-42.

2. Liu, J., J.D. Farmer, Jr., W.S. Lane, J. Friedman, I. Weissman, and S.L. Schreiber. 1991. Calcineurin is a common target of cyclophilin-cyclosporin A and FKBP-FK506 complexes. Cell. 66:807-815.

3. Clipstone, N.A., and G.R. Crabtree. 1992. Identification of calcineurin as a key signalling enzyme in T-lymphocyte activation. Nature (Lond.). 357:695697.

4. O'Keefe, S.J., J. Tamura, R.L. Kincaid, M.J. Tocci, and E.A. O'Neill. 1992. FK-506-and CsA-sensitive activation of the interleukin-2 promoter by calcineurin. Nature (Lond.). 357:692-694.

5. Frantz, B., E.C. Nordby, G. Bren, N. Steffan, C.V. Paya, R.L. Kinkade, M.J. Tocci, S.J. O'Keefe, and E.A. O'Neill. 1994. Calcineurin acts in synergy

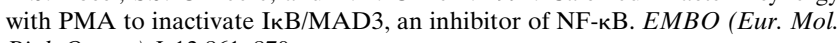
Biol. Organ.) J. 13:861-870.

6. Mattila, P.S., K.S. Ullman, S. Fiering, E.A. Emmel, M. McCutcheon, G.R. Crabtree, and L.A. Herzenberg. 1990. The action of cyclosporin A and FK506 suggest a novel step in the activation of T lymphocytes. EMBO (Eur. Mol. Biol. Organ.) J. 9:4425-4433.

7. Baeuerle, P.A., and T. Henkel. 1994. Function and activation of NF-кB in the immune system. Annu. Rev. Immunol. 12:141-179.

8. Beg, A.A., and A.S. Baldwin, Jr. 1993. The IкB proteins: multifunctional regulators of Rel/NF-кB transcription factors. Genes \& Dev. 7:2064-2070.

9. Yamamoto, K., K. Nakayama, H. Shimizu, K. Mitomo, and K. Fujimoto. 1992. Molecular mechanisms for the regulation of inflammation. Prog. Immunol. 8:369-376.

10. Auphan, N., J.A. DiDonato, C. Rosette, A. Helmberg, and M. Karin. 1995. Immunosuppression by glucocorticoids; inhibition of NF-кB activity through induction of IkB synthesis. Science (Wash. DC). 270:286-290.

11. Scheinman, R.I., P.C. Cogswell, A.K. Lofquist, and A.S. Baldwin. 1995. Role of transcriptional activation of $\mathrm{I} \kappa \mathrm{B} \alpha$ in mediation of immunosuppression by glucocorticoids. Science (Wash. DC). 270:283-286.

12. Ishibashi, M. 1991. Japnese study of FK 506 on kidney transplantation: results of an early phase II study. Transplant. Proc. 23:3071-3074.

13. Jain, A.B., J.J. Fung, S. Todo, M. Alessiani, S. Takaya, K. Abu-Elmagd, A. Tzakis, and T. Starzl. 1991. Incidence and treatment of rejection episodes in primary orthopic liver transplantation under FK 506. Transplant. Proc. 23:928930.

14. Shapiro, R., M. Jordan, J. Fung, J. McCauley, J. Johnston, Y. Iwaki, A. Tzakis, T. Hakala, S. Todo, and T.E. Starzl. 1991. Kidney transplantation under FK 506 immunosuppression. Transplant. Proc. 23:920-923.

15. Kishimoto, T. 1989. The biology of interleukin-6. Blood. 74:1-10.

16. Horii, Y., A. Muraguchi, M. Iwano, T. Matsuda, T. Hirayama, H. Yamada, Y. Fujii, K. Dohi, H. Ishikawa, Y. Ohmoto, K. Yoshizaki, T. Hirano, and T. Kishimoto. 1989. Involvement of IL-6 in mesangial proliferative glomerulonephritis. J. Immunol. 143:3949-3955.

17. Brandt, S.J., D.M. Bodine, C.E. Dunbar, and A.W. Nienhuis. 1990. Dysregulated interleukin 6 expression produces a syndrome resembling Castleman's disease in mice. J. Clin. Invest. 86:592-599.

18. Fattori, E., C. Della Rocca, P. Costa, M. Giorgio, B. Dente, L. Pozzi, and G. Ciliberto. 1994. Development of progressive kidney damage and Myeloma kidney in interleukin-6 transgenic mice. Blood. 83:2570-2579.

19. Suematsu, S., T. Matsuda, K. Aozaka, S. Akira, N. Nakano, S. Ohno, J. Miyazaki, K. Yamamura, T. Hirano, and T. Kishimoto. 1989. IgG1 plasmacytosis in interleukin 6 transgenic mice. Proc. Natl. Acad. Sci. USA. 86:7547-7551.

20. Wijnen, R.M.H., B.G. Ericzon, A.T.G.M. Tiebosch, A.J. Beysens, C.G. Groth, and G. Kootstra. 1991. Toxicity of FK 506 in the cynomolgus monkey: noncorrelation with FK 506 serum levels. Transplant. Proc. 23:3101-3104.

21. Davis, N., S. Ghosh, D.L. Simmons, P. Tempst, H.-C. Liou, D. Baltimore, and H.R.J. Bose. 1991. Rel-associated pp40: an inhibitor of the rel-family of transcription factor. Science (Wash. DC). 253:1268-1271.

22. Mizushima, S., and S. Nagata. 1990. pEF-BOS, a powerful mammalian expression vector. Nucleic Acids Res. 18:5322.

23. Shimizu, H., K. Mitomo, T. Watanabe, S. Okamoto, and K. Yamamoto. 1990. Involvement of a NF-кB-like transcription factor in the activation of the interleukin-6 gene by inflammatory lymphokines. Mol. Cell. Biol. 10:561-568. 
24. Dignam, J.D., R.M. Lebovitz, and R.G. Roeder. 1983. Accurate transcription initiation by RNA polymerase II in a soluble extract from isolated mammamlian nuclei. Nucleic Acids Res. 11:1475-1489.

25. Nakayama, K., H. Shimizu, K. Mitomo, T. Watanabe, S. Okamoto, and K. Yamamoto. 1992. A lymphoid cell-specific nuclear factor containing c-rellike protein preferentially interacts with interleukin- $6 \kappa \mathrm{B}$-related motifs whose activities are repressed in lymphoid cells. Mol. Cell. Biol. 12:1736-1746.

26. Cathala, G., J.F. Savourret, B. Mendez, B. West, M. Karin, J. Martial, and J.D. Baxter. 1983. Improved methodology for isolation of intact and highly active ribonucleic acid. $D N A(N Y)$. 2:329-335.

27. Nakajima-Iijima, S., H. Hamada, P. Reddy, and T. Kakunaga. 1985. Molecular structure of the human cytoplasmic $\beta$-actin gene: interspecies homology of sequences in the intron. Proc. Natl. Acad. Sci. USA. 82:6133-6137.

28. Tamura, K., M. Kobayashi, K. Hashimoto, K. Kojima, and K. Nagase. 1987. A highly sensitive method to assay FK-506 levels in plasma. Transplant. Proc. 19:23-29.

29. Snyder, S.H., and D.M. Sabatini. 1995. Immunophilins and the nervous system. Nature Med. 1:32-37.

30. Venkataramanan, R., A. Jain, E. Cadoff, V. Warty, K. Iwasaki, K. Nagase, A. Krajack, O. Imventarza, S. Todo, J.J. Fung, and T.E. Starzl. 1990. Pharmacokinetics of FK506: preclinical and clinical studies. Transplant. Proc. 22:5256.

31. Yamaguchi, Y. 1991. Clinicopathological evaluation of kidney transplants in patients given a fixed dose of FK 506. Transplant. Proc. 23:3111-3115.

32. Demetris, A.J., B. Banner, J. Fung, R. Shapiro, M. Jordan, and T.E. Starzl. 1991. Histopathology of human renal allograft rejection under FK 506: a comparison with Cyclosporin. Transplant. Proc. 23:944-946.
33. Schreck, R., P. Rieber, and P.A. Baeuerle. 1991. Reactive oxygen intermediates as apparently widely used messengers in the activation of the NF-кB transcription factor and HIV-1. EMBO (Eur. Mol. Biol. Organ.) J. 10:22472258

34. Davis, R.J. 1993. The mitogen-activated protein kinase signal transduction pathway. J. Biol. Chem. 268:14533-14556.

35. Stancato, L.F., Y.H. Chow, J.K. Owens Grillo, A.W. Yem, M.R. Deibel, Jr., R. Jove, and W.B. Pratt. 1994. The native v-Raf.hsp90.p50 heterocomplex contains a novel immunophilin of the FK506 binding class. J. Biol. Chem. 269: 22157-22161.

36. Finco, T.S., and A.S.J. Baldwin. 1993. $\mathrm{kB}$ site-dependent induction of gene expression by diverse inducers of nuclear factor $\kappa \mathrm{B}$ requires Raf-1. J. Biol. Chem. 268:17676-17679.

37. Brillantes, A.B., K. Ondrias, A. Scott, E. Kobrinsky, E. Ondriasova, M.C. Moschella, T. Jayaraman, M. Landers, B.E. Ehrlich, and A.R. Marks. 1994. Stabilization of calcium release channel (ryanodine receptor) function by FK506-binding protein. Cell. 77:513-523.

38. Sha, W.C., H.-C. Liou, E.I. Tuomanen, and D. Baltimore. 1995. Targeted disruption of the p50 subunit of NF-кB leads to multifocal defects in immune responses. Cell. 80:321-330.

39. Rosen, S., Z. Greenfeld, and M. Brezis. 1990. Chronic cyclosporininduced nephropathy in the rat. Transplantation (Baltimore). 49:445-452.

40. Moutabarrik, A., M. Ishibashi, M. Fukunaga, H. Kameoka, N. Kawaguchi, Y. Takano, Y. Kokado, T. Sonoda, S. Onishi, S. Takahara, et al. 1992. FK506-induced kidney tubular cell injury. Transplantation (Baltimore). 54: 1041-1047. 